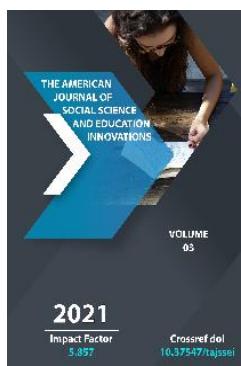

\title{
History And Transmission Of Medical Terminology
}

Odina Toychieva

Fergana Public Health Medical Institute, Uzbekistan

Journal Website:

http://theamericanjour

nals.com/index.php/taj

ssei

Copyright: Original content from this work may be used under the terms of the creative commons attributes

4.0 licence.

\section{ABSTRACT}

The aim of our article is to research the technical Latinisms in German with the help of a comprehensive analysis. We try to analyze the Latinisms in German and to offer German learners in the field of medicine an overview of the loanwords in tabular form, which they can use to make a decision in unclear cases.

\section{KEYWORDS}

Diarrhea, catarrh, apoplexy, humoral pathology, bile, blood juice, choleric, melancholic, phlegm.

\section{INTRODUCTION}

The roots of Western medicine go back a long way to antiquity. Many modern disease names, such as apoplexy, catarrh or diarrhea are already in the 5 th century $B C$ in the Hippocratic Medicine. In contrast to the colloquial use, a special medical meaning can already be

demonstrated at this time, which speaks for a conceptual narrowing of such terms. 
The literal meaning of such expressions as stroke flow (apoplexy), flow down (catarrh) or flow (diarrhea) refers to the humoral pathological concept of disease in ancient medicine. The interpretation of the disease phenomena, the explanation of the disease and its treatment at that time were carried out under a different theoretical premise than in modern medicine. As the term humoral pathology (humores = body fluids) makes clear, the liquid body components and body excretions were given a very special weight. According to humoral pathology, health consists of the respective individual mixing ratio (eukrasia $=$ good mixture) of four body fluids (yellow bile, black bile, blood juice and mucus), according to the personal temperament; illness therefore consists of a disproportion between these juices (dyscrasia = bad mixture), which needs to be compensated therapeutically.

\section{MATERIAL AND METHODS}

Hippocratic medicine created a physiological conception that culminated in the formulation of the so-called humourapathological fourway scheme, taking into account the Aristotelian theory of elements. Four cardinal juices - consisting of pairs of opposites - with their equally opposing qualities form the healthy mixture of the body. The doctrine of character still comprehensible today in popular belief, goes back to them, which sets certain essential characteristics in relation to the bodily fluids. The quick-tempered and irascible nature of the choleric is attributed to the predominance of yellow bile, the gloomy and sad disposition of the melancholic to black bile, the excited, overheated or even cheerful nature of the sanguine to the blood sap and the indolence of the phlegmatic to the viscous phlegm, who determines his essence.

Strictly speaking, different humoralpathological concepts existed side by side during ancient Greece and Rome, which differed in the number of basic elements or basic juices as well as through their different weighting between qualities and juices. With Galen's attempt at a comprehensive synthesis of all contemporary knowledge - and the Canonization of his writings following the Arab-Islamic tradition - humoral pathology got its form, which is binding for Western medicine.

The idea of the juices and the interpretation of the physis as an immaterial natural work made an investigation of the solid structures of the body superfluous, so that no greater anatomical or morphological interest arose. According to the humoral pathological view, diseases were based on the wrong mixture of the juices, the pathological substrate of which was also regarded as materia peccans. Therapeutic interventions were primarily aimed at balancing the juices, excreting the disease-causing materia peccans or supporting the physique of the sick body in neutralizing or boiling off the disease-causing substances.

\section{DISCUSSION AND CONCLUSION}

It must be emphasized for this model of thought that illness was viewed as an event that did not affect a part of the body, but always affected the whole person. In this context, illness was understood more as a disease, not as a delimitable event that could be isolated as a clinical picture, but as a condition that could not be separated from the patient's individual life. In the humoral pathological tradition, therefore, the determination of regular symptom complexes, i.e. diseases in the modern sense, played more a role than the description of the respective individual symptom combination.

Up until the early 19th century, conventional medicine was based on the basic principles of humoral pathology. Originally, the term orthodox medicine was primarily directed against this school tradition of medicine and 
characterized it as a rigid system that is locked into fixed thought structures. However, the word conventional medicine was only properly established as a fighting term by homeopathy and naturopathy in the second half of the 19th century.

Tradition of the medical terminology. The humoral pathology received a uniform anatomical and physiological - conception in the writings of Galen (129 - approx. 210), who made a systematic presentation of the medical knowledge known at the time. Although Galen mainly lived and worked in Rome, his works were written in Greek, the scientific and standard language of the time. Thus, the medical works spread over the territories of the Roman Empire in Greek. Even after the fall of Rome, the Greek tradition was continued through the Eastern Roman Empire in the eastern Mediterranean, although many of the scriptures were translated. In this way, ancient medicine - and its technical expressions - was taken up and further developed in the Arab sciences from the 9th century, partly directly, partly through the Syrian and Persian medical schools. A prominent example is the compilation, systematization and enrichment of the galenic script canon by Ali al-Husain ibn Abd Allah ibn Sina, latinized as Avicenna (980-1037). His writings formed - in Latin translation - one of the most important foundations of medieval and early modern medicine.

If Latin elements predominate in medical terminology today, this is mainly due to the importance of Latin as a binding lingua franca since the Middle Ages. The medical and scientific knowledge of the Arab world also became known in the West through Latin. Since the early Middle Ages, many ancient medical writings that were believed to be lost have been translated from Arabic into Latin. Important centers were the medical schools founded around 900 AD in Salerno (southern Italy) and in Toledo (southern Spain), where under Arab rule a flourishing and fruitful exchange between Muslims, Christians and Jews was possible (until the conquest by the Castilian kings in the 15th century). Today, however, there are only a few traces of Arabic in medical terminology. Examples: alcohol, alchemy (aka alchemy), elixir

In the late 15th and 16th centuries (humanism), many writings were translated from the Greek original into Latin. But these different ways of reception and intertwined translation traditions meant that sometimes (in the eyes of classical scholars) mutilated or crude word formations were taken over into technical language (examples: Pia mater, actually = pious mother; in medical terminology $=$ soft meninges). In the Renaissance efforts were made to revive the ancient ideals. The work by Andreas Vesal (1514-1564), which was a tradition-building work for anatomical terminology, was written in classical Latin, as was the work by William Harvey (1578-1657) on blood circulation.

Until well into modern times, Latin remained the language of scholars, which allowed communication beyond the boundaries of the respective mother tongue. For example, clinical lectures at Berlin University were held in Latin until the mid-19th century, and it was still quite common at that time for medical students to prove their practical aptitude by translating a few passages from Galenic or Hippocratic writings had to. This "old language" orientation corresponded to the "new humanist education program" which - at least in part - was implemented by the Prussian reform universities.

This self-evident basis of communication was lost at the end of the 19th century when, with the Realgymnasium, the philological schooling was increasingly supplemented and finally replaced by a mathematical-natural-scientific school education. Nonetheless, the medical terminology remained committed to Latin and Greek; indeed, in the course of the disciplinary development of scientifically oriented 
medicine, new specialist terms were formed from Greek on a large scale. University medicine continued to orient itself towards a humanistic educational ideal. Even after 1945 there was no fundamental university reform neither in the western zones nor in the Soviet occupation zone. In East Germany, for example, so-called pre-study institutions were set up, which were supposed to enable an intensified and faster introduction of sections of the population who had been discriminated against by the traditional education system up to now. The education system and its university educational ideals themselves were not called into question.

\section{ACKNOWLEDGEMENT}

When the long delayed university reform began in the FRG at the end of the 1960s, the entry requirement for the Latin high school was abolished. Since then it has no longer been taken for granted that students in the first semester have knowledge of Latin or even ancient Greek. With good reason, however, in 1970 when the license to practice medicine was passed, medical students up to Physics were not required to provide evidence of minor Latinism. In order to impart the basics of medical terminology and medical communication as well as their responsible use, the terminology course was introduced instead, for which the Institutes for the History of Medicine are responsible to this day.

\section{REFERENCES}

1. Ehnert, R. / Piepho, H.-E.: Learning foreign languages with the media. Ismaning: Hueber, 1986.

2. Fluck, H.-R.: "Problems and Tasks of Didactics of Specialized Languages". German Lessons 31 (1999)
3. Franz Pera and Heinz-Peter Schmiedebach, medical vocabulary, compact terminology, Walter de Gruyter, Berlin • New York 2007

4. Geldmacher, M., presentation skills in high school German lessons. Goals, content, methods, Baltmannsweiler: Schneider Verlag Hohengehren, 2010.

5. Klauke, M.: "Technical texts, technical text types, technical text structures". Schaeder, B.: Technical languages and specialist communication in research, teaching and professional practice. Volume 54. Essen: Die Blaue Verlag, 1994

6. Krumm, H.J., German as a Foreign and Second Language: 2nd half-volume, 2010

7. Riesel, E. "Deutsche Stilistik" 1975, S 84 Moskou 1975 Verlag Hochschule

8. Stäudel, L., Franke-Braun, G., Parchmann, I. (2008). Language, communication and knowledge acquisition in chemistry classes

9. www.

lexikon.freenet.de/Literaturdidaktik

10. www.allesgelingt.de

11. www.lehrer-online.de 